\title{
Scope of X-Chromosomal MiniSTRs: Current Developments
}

\author{
Muhammad Israr ${ }^{1,2^{*}}$, Sehrish Rafiq ${ }^{1,3}$, Ahamad Ali Shahid ${ }^{1}$, Haroon Hussain ${ }^{2}$ and Allah Rakha ${ }^{2}$ \\ ${ }^{1}$ National Centre of Excellence in Molecular Biology, University of the Punjab, 87-West Canal Bank Road, Lahore-53700, Pakistan \\ ${ }^{2}$ Department of Forensic Sciences, University of Health Sciences, Lahore, Pakistan \\ ${ }^{3}$ University of Veterinary and Animal Sciences, Lahore, Pakistan
}

"Corresponding author: Muhammad Israr, Department of Forensic Sciences, University of Health Sciences, Khayaban-e-Jamia Punjab, Lahore-54600, Pakistan, Tel: +923339359598; E-mail: israr@uhs.edu.pk

Received date: Apr 23, 2014, Accepted date: Sep 23, 2014, Publication date: Sep 26, 2014

Copyright: (c) 2014 Israr M, et al. This is an open-access article distributed under the terms of the Creative Commons Attribution License, which permits unrestricted use, distribution, and reproduction in any medium, provided the original author and source are credited.

\begin{abstract}
The experience of using autosomal short-length amplicon STRs or miniSTRs in profiling of degraded DNA and mass disaster victims is extended into the realm of X-chromosomal ( $\mathrm{hrX}$ ) STR miniaturization. About half of the total X-STRs are now short-length amplicons and the focus is shifting to using the mini versions of all of them. Joint multiplexing of these loci can be used for solving complex paternity cases and association of mass disaster victims with their families. This technology may herald a new dimension for research in population genetics and evolution. We present an overview of the progress made thus far and the future scope and prospects for X-miniSTRs.
\end{abstract}

Keywords: Degraded DNA analysis; Mini-STRs; X-chromosomal STRs

\section{Introduction}

Sherlock Holmes said, "I had come to an entirely erroneous conclusion which shows how dangerous it always is to reason from insufficient data" [1]. A century later, forensic science has moved forward a long way and instead of crime psychology, it is the empirical evidence that is of interest to a forensic scientist. But now it is even more necessary to have sufficient data for accurate analysis in a forensic laboratory lest the faulty evidence be responsible for the conviction of an innocent citizen [2,3]. As forensic science and its techniques advance, so do the techniques of the perpetrators of the crimes. Moreover, environmental pollution further confounds the evidence found at a crime scene or samples left on a mass disaster site. Hence, there is a constant pressure to develop novel and precise methods to identify the guilty but to exonerate the innocent or to accurately identify a missing relative. From fingerprinting to DNA profiling, many techniques were standardized and discarded until the data basing of core Short Tandem Repeats (STR) loci. Since then, millions of profiles have been generated and now STRs are the workhorses for forensic testing [4].

In forensic casework we are often faced with samples that are not in the best of conditions and consist of DNA that is highly fragmented. This includes burnt items, bones and teeth. Exposure to heat and humidity, aids in the breaking down of DNA molecules to smaller fragments. Nucleases from within the cell attack the DNA as soon as the cell dies, leading to its degradation [5]. Biochemical, microbial or oxidative process can also lead to DNA degradation. In favourable environment DNA is rendered highly fragmented by microbes. Bacteria are the main agents on land while fungi are responsible for oceanic degradation [6,7]. Slightly degraded samples can be typed by traditional STRs, but may yield negative results as the fragmentation increases [8-10]. Conventional STRs have a size range of 100-400 bp most of which consists of flanking sequences on both sides of the repeat region. To alleviate the problems associated with analyzing
DNA from degraded samples a new set of STR primers known as Miniplexes were designed by moving the primers closer to the repeat region leaving the extra sequences out $[11,12]$. Using shorter amplicons in polymerase chain reaction (PCR), improvement has been reported in obtaining results from forensic evidence or a mass disaster site having degraded specimens [13].

The DNA typing has played a pivotal role to establish the paternity of child which is utmost priority for support, inheritance right and other social benefits of a child. Short Tandem Repeats (STRs) located on $\mathrm{X}$ chromosome are powerful marker for complex kinship testing such as deficiency paternity testing when the disputed child is a female [14-16].

X-STRs are currently used in parentage analysis and relationship investigations such as avuncular and first cousin relationships. In addition to X-STRs, stable haplotype of closely associated Xchromosome markers have proven to be a powerful tool in kinship analysis especially for cases when father/daughter relationships are to be tested. X-STRs have also advantage over autosomal STRs for paternity cases involving close blood relatives as alternative putative fathers and in deficiency paternity cases, i.e. when the DNA sample from putative father is not available and DNA from paternal relative has to be analyzed instead [17]. Further, X-linked STRs can be used to solve sibship status, without using father's DNA, of two females having the same biological father $[18,19]$. X-STRs can determine the relationship of grandmother/granddaughter as granddaughter theoretically has to carry at least one allele in common with the grandmother [20]. In forensic analysis of mixed stains, X-STRs are helpful to identify the female DNA $[21,22]$.

\section{History and Progression}

The world first came to know about short amplicon STR in 1994s when the British Forensic Science Service (FSS), while running degraded DNA samples from the remains of victims of the Branch Davidian fire in Waco, Texas, found that smaller STRs in their 4-plex work better than the larger loci [23] which was subsequently 
corroborated by Clayton et al. [24]. Wiegand et al. (2001) described that by redesigning the primers, the length of the amplicons can be reduced [25]. However, the real work started when the World Trade Centre Kinship and Data Analysis Panel (WTC KADAP), was formed to identify victims of the WTC attacks using DNA testing and the name "miniSTR" was coined. In 2004, a collaborative study between nine European and US laboratories was organised under the auspices of the European DNA Profiling group (EDNAP) on the same sets of degraded samples. The results were collated and analysed and, in general, mini-STR systems were shown to be the most effective [26]. Since then, a number of other studies have demonstrated that successful analysis of degraded DNA specimens from mass disasters or compromised forensic evidence improves with smaller-sized PCR products [8,10,12,14,27-31]. The TIMELINE (Figure 1) shows the progress of ChrX miniSTRs over the years [32-46].

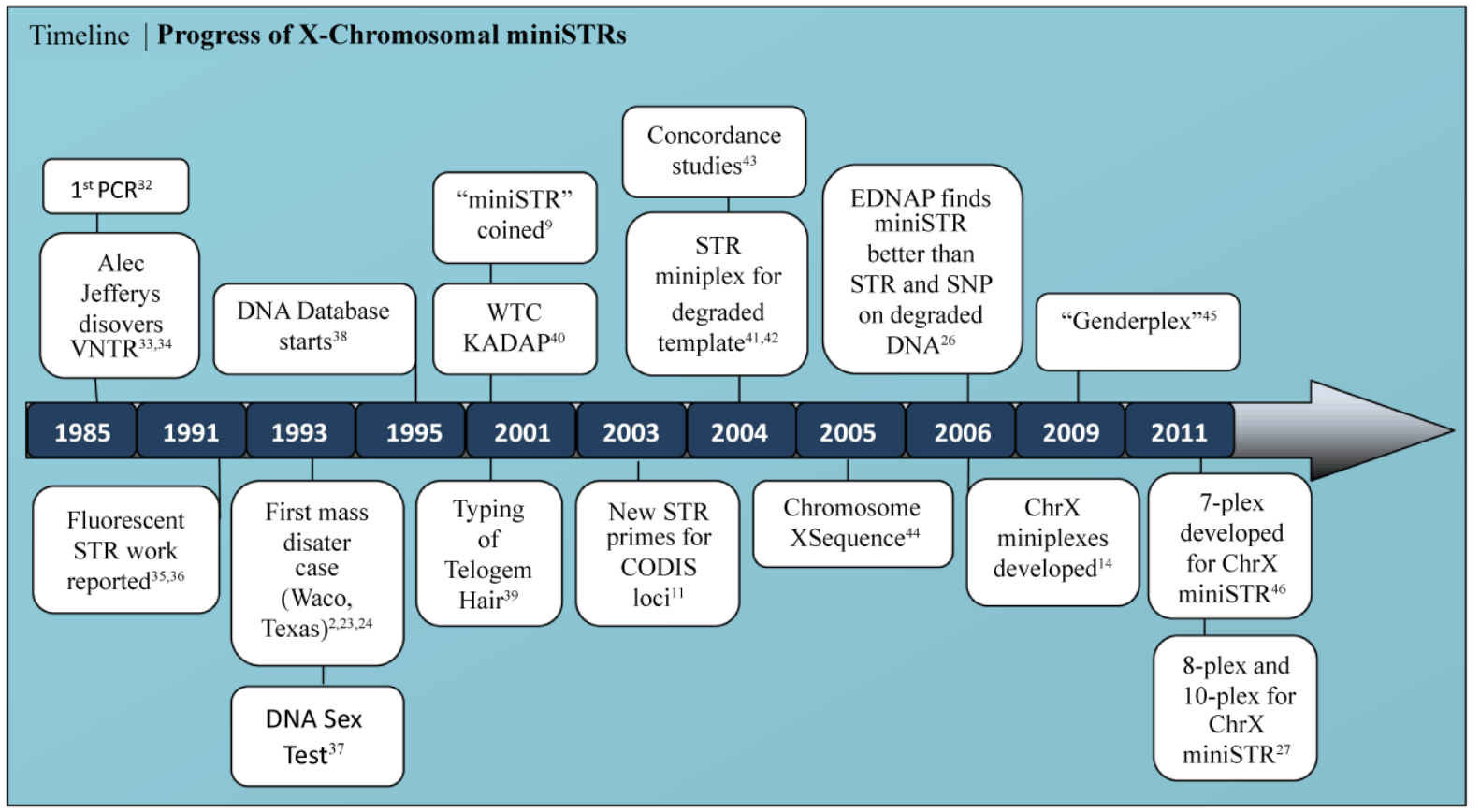

Figure 1: Evolution of miniSTRs - a Timeline. PCR=Polymerase Chain Reaction, VNTR=Variable Number Tandem Repeats, STR $=$ Short Tandem Repeats, WTC KADAP=World Trade Centre Kinship and DNA Analysis Panel, CODIS=COmbined DNA Indexing System, EDNAP=European DNA Profiling group, $\mathrm{ChrX}=\mathrm{X}$-Chromosome.

\section{X-Chromosomal STRs and miniSTRs: Identity Testing and Beyond}

Due to its unique inheritance pattern, the $\mathrm{X}$ chromosome is a potential candidate for forensic and human identity testing applications. Normal males possess one $\mathrm{X}$ chromosome and one $\mathrm{Y}$ chromosome, whereas females possess two X chromosomes. Now, more than $40 \mathrm{X}$-STRs have been established as forensic markers [47-50]. The majority of X-STRs can be used routinely and there are no peculiarities in terms of their usage except HumARA, one of the established STR markers. It has been recommended recently that HumARA should not be used as a forensic marker [51] due to its association with bulbar muscular atrophy [52]. X-STR haplotyping can be of particular help in kinship testing with deficient paternity cases where a DNA sample from one of the parents is not available for testing. For example, if a father/daughter parentage relationship is in question, X-STRs may be helpful [53-57].

Usually ChrX markers are less powerful in stain analyses than autosomal markers and are not suitable for use in the testing of male traces where there is female contamination. However, these are more powerful than autosomal markers for identification of female traces in male contamination [58].
The ideal technique for forensic DNA typing is multiplex PCR because as the number of polymorphic loci examined increases, the probability of identical alleles, being present in two different individuals, decreases [59]. Multiplex systems have been developed to use the X-STRs efficiently for paternity testing. The first multiplex study with respect to X-STRs analysed nine loci in three different multiplexes which included duplex PCR (DXS6789 and DXS6795), Triplex PCR (DXS7133, DXS9895 and DXS9898) and Quadruplex PCR (DXS6803, DXS8378, GATA164A09, and DXS7132) [60]. In a very short period of time, other studies came up with parallel amplification of three [61], four [62,60], five [63,64], six [65], seven [66], eight [67] ten [15], eleven [68], twelve [69], and thirteen [70,71], $\mathrm{X}$-STR markers. Multiplexes with a greater number of markers are being developed to obtain a higher degree of discrimination.

However, work on ChrX miniSTRs is very slow as compared to autosomal miniSTRs. As reported in the literature, the amplicon size of a miniSTR is below 200bp, above which chances of getting a complete profile from a degraded sample diminish significantly [42]. Others have suggested that the optimum product size is below 150bp [26]. Only a handful of studies are available on ChrX miniSTRs which are often combined with other larger-amplicon size markers, hence making them unsuitable for use in degraded sample studies and 
Page 3 of 6

casework. These markers along with amplicon size range are given in Table 1.

In the table, STRs namely, DXS10147, DXS10160, DXS10162, DXS9902 and DXS10103 are barely under the threshold level for "mini" and hence not suitable for inclusion in a miniplex.

\begin{tabular}{|c|c|c|}
\hline Marker & Size (in base pairs) & Reference \\
\hline AMELX, AMELY & $X=55, Y=58$ & [45] \\
\hline DXS7424 & $79-100$ & [14] \\
\hline AMELX, AMELY & $X=80, Y=83$ & [72] \\
\hline GATA165B12 & $90-110$ & [14] \\
\hline DXS6795 & $90-111$ & [60] \\
\hline GATA31E08 & $101-133$ & [14] \\
\hline DXS8378 & $95-111$ & [14] \\
\hline DXS7423 & $99-115$ & [14] \\
\hline AMELX, AMELY & $X=106, Y=112$ & [72] \\
\hline DXS7133 & $106-130$ & [73] \\
\hline GATA172D05 & $108-136$ & [73] \\
\hline DXS6803 & $109-128$ & [74] \\
\hline DXS7130 & $109-128$ & [74] \\
\hline DXS6801 & $113-137$ & [75] \\
\hline DXS10163 & $121-171$ & [76] \\
\hline DXS6789 & $122-162$ & [14] \\
\hline DXS7132 & $131-155$ & [73] \\
\hline DXS10160 & $135-193$ & [77] \\
\hline DXS9895 & $139-161$ & [73] \\
\hline DXS101 & $142-169$ & [14] \\
\hline HPRTB & $144-176$ & [22] \\
\hline DXS10165 & $145-173$ & [76] \\
\hline DXS7424 & $147-174$ & [78] \\
\hline DXS10162 & $150-186$ & [76] \\
\hline DXS10159 & $154-190$ & [76] \\
\hline DXS10103 & $160-200$ & [79] \\
\hline DXS9902 & $162-186$ & {$[27]$} \\
\hline DXS10147 & $165-185$ & {$[80]$} \\
\hline
\end{tabular}

Table 1: MiniSTRs of X-Chromosome along with their product size and references.

The first mini-only multiplex for ChrX STRs was reported by Asamura and colleagues [14]. Designing new primers, they devised two 4-plexes consisting of X-STR loci, DXS7424, DXS101, DXS7423, DXS6789, DXS8378, DXS7133, GATA165B12 and GATA31E08. The miniplex strategy was shown to be effective for the analysis of degraded DNA based on the results of tests with these multiplexes. It was concluded that for personal identification, these multiplex systems offered high effectiveness with degraded DNA samples [14]. However, the problem in their approach is that for any meaningful results, a large quantity of sample is required to perform analysis with so many miniplexes, thus defeating the very purpose of miniSTRs. Samples from a mass disaster site or from an environmentally exposed crime scene may not be only highly degraded but also in very scarce quantity making it difficult for the scientist to perform multiple PCR analyses [53]. In 2011, a 7-plex was developed [46] while an 8-plex and 10-plex were reported elsewhere [27].

In the criminal justice system, it is not uncommon that, due to circumstantial evidence, a person is indicted and sent to jail but years later proved to be innocent through the use of DNA typing [81]. Since evidence is not always found in a very 'DNA-friendly' environment, degradation is one of the most common hindrances in such cases. MiniSTRs have the ability to provide reliable profiles from old samples [82] and, hence, may be used to set the innocent free.

There are several measures like variation in allele size and frequency, heterozygosity, genetic variability and discontinuous allele distribution, which are useful in population genetics. These miniSTRs may be powerful in the study of population genetics and can be used to detect changes due to mutations or genetic drift among populations [83]. Being lineage markers, these can also be used as ancestry informative markers to deduce individual ancestry information from admixture populations [84]. The X chromosome, along with Ychromosome and mitochondrial DNA, has tremendous potential for the reconstruction of phylogenetic trees to unravel the complexities of the history of populations. But we need many loci for this kind of work and with the help of miniaturization of X-STRs, we would be better equipped to tackle this problem [85].

Another avenue where miniSTRs are potential candidates for use is the study of ancient samples such as found inside and around the archaeological digs. Since the DNA found in sites like these is expected to be highly degraded, only short DNA templates of up to $300 \mathrm{bp}$ are present [86] making it challenging for any meaningful analysis with traditional STRs. These 'minis' can prove essential where other anthropological methods cannot be applied for sex typing, phylogenies [87] and to explore the gender differences in the past populations [88, 89]. Although SNPs are potential candidates for use with degraded samples, problems like low polymorphism and difficulty in mixture interpretation hinders their widespread use, outside the research setting [90].

\section{Miniaturization: Problems and Prospects}

There has been substantial progress with shortening the length of many ChrX STRs amplicons during the last decade. But there are significant problems which hinders the process of miniaturization. Foremost among these is that, due to size limitation, not many STRs can be fit together in a single multiplex and most of the time only one marker or two markers per dye are run to avoid overlap. This approach normally makes a maximum of 5-10 miniSTRs in a single multiplex using the 6-dye chemistry.

Secondly, most human identity testing applications require a high degree of polymorphism and, hence, a wider allele frequency distributions. In multiplexes, these markers consume precious electrophoretic space. However, in some parentage testing situations, 
less polymorphic loci having lower mutation rates are more useful. For example, mutation rates are not significant when evidence is compared directly with a suspect [91]. But in parentage and kinship testing where comparison between relatives is done, as for identification of mass disaster victims, mutational events become important [92]. STRs having long homogenous repeat structures are prone to instability such as DXS8377 and DXS10011 [49] and are, therefore, not suitable for use [93]. Hence, STR loci possessing a smaller size range and sufficiently polymorphic are being characterized [12].

Thirdly, miniSTR primers anneal to different locations than those of the conventional STR primers, and polymorphic nucleotides or insertion/deletions may be present in the flanking regions surrounding the STR repeats. Discordant results may be produced due to allele dropout and size shifts in amplicons generated from one of the primer sets $[94,95]$.

Fourthly, there are analytical issues attached to the miniaturization approach. When the size is reduced to less than $150 \mathrm{bp}$, the biggest problem comes from dye blobs. These may be left over from the oligonucleotide synthesis process or may result from dyes falling off the primer during the heating and cooling steps of PCR [76].

Lastly, smaller PCR products have a problem in the manner in which sizing is performed using an internal lane standard. Local Southern, the default method used by the GeneScan software, requires two peaks from the internal size standard to be present on either side of a peak being defined. Hence, both 35 and 50bp peaks from the GS500 Liz size standard must be defined for measuring any allele below $75 \mathrm{bp}$ [11]. Due to the presence of primer dimers in the smaller sizing area, sizing peaks may become ambiguous. Therefore, it is recommended that Global Southern, where a regression line generated from all sizing peaks is used to fit the STR alleles, be the method of choice for small-size amplicons [96].

\section{Conclusion}

X-chromosomal miniSTRs offer a new potential tool for recovering useful information from samples that are otherwise difficult to generate full profiles. These miniplexes are valuable in the analysis of samples where allele dropout and reduced sensitivity of larger STR alleles occur. They are also useful for improving the power of exclusion in mass disaster cases where there are insufficient family references for association. In complex paternity cases, these loci can provide additional discrimination in parentage analysis. It should be kept in mind that the purpose of these miniSTRs is not to replace but to supplement the current battery of autosomal core loci where samples are degraded or there is not enough reference material available for identification profiles. It would prove useful if future loci for consideration in forensic casework applications contain a more compact allele range and be able to be amplified as small PCR products.

\section{References}

1. Conan-Doyle A (1930) The adventure of the speckled band. The complete Sherlock Holmes 1: 257-273.

2. Lygo JE, Johnson PE, Holdaway DJ, Woodroffe S, Whitaker JP, et al. (1994) The validation of short tandem repeat (STR) loci for use in forensic casework. Int J Legal Med 107: 77-89.

3. Coovadia A (2008) And the helix may set you free. J Assoc Genet Technol 34: 11-12.
4. Gill P, Werrett DJ, Budowle B, Guerrieri R (2004) An assessment of whether SNPs will replace STRs in national DNA databases--joint considerations of the DNA working group of the European Network of Forensic Science Institutes (ENFSI) and the Scientific Working Group on DNA Analysis Methods (SWGDAM). Sci Justice 44: 51-53.

5. El-Harouny E, El-Dakroory S, Attalla S, Hasan N, Hassab El-Nabi S (2009) The relationship between postmortem interval and DNA degradation in different tissues of drowned rats. Internet J Forensic Sci: 4.

6. Butler JM (2006) MiniSTRs: past, present, and future. Forensic News published.

7. Leahy JG, Colwell RR (1990) Microbial degradation of hydrocarbons in the environment. Microbiol Rev 54: 305-315.

8. Grubwieser P, Mühlmann R, Berger B, Niederstätter H, Pavlic M, et al. (2006) A new "miniSTR-multiplex" displaying reduced amplicon lengths for the analysis of degraded DNA. Int J Legal Med 120: 115-120.

9. Holland MM, Cave CA, Holland CA, Bille TW (2003) Development of a quality, high throughput DNA analysis procedure for skeletal samples to assist with the identification of victims from the World Trade Center attacks. Croat Med J 44: 264-272.

10. Parsons TJ, Huel R, Davoren J, Katzmarzyk C, Milos A, et al. (2007) Application of novel "mini-amplicon" STR multiplexes to high volume casework on degraded skeletal remains. Forensic Sci Int Genet 1: 175-179.

11. Butler JM, Shen Y, McCord BR (2003) The development of reduced size STR amplicons as tools for analysis of degraded DNA. J Forensic Sci 48: 1054-1064.

12. Coble MD, Butler JM (2005) Characterization of new miniSTR loci to aid analysis of degraded DNA. J Forensic Sci 50: 43-53.

13. Chung DT, Drábek J, Opel KL, Butler JM, McCord BR (2004) A study on the effects of degradation and template concentration on the amplification efficiency of the STR Miniplex primer sets. J Forensic Sci 49: 733-740.

14. Asamura H, Sakai H, Kobayashi K, Ota M, Fukushima H (2006) MiniXSTR multiplex system population study in Japan and application to degraded DNA analysis. Int J Legal Med 120: 174-181.

15. Gomes I, Alves C, Maxzud K, Pereira R, Prata MJ, et al. (2007) Analysis of 10 X-STRs in three African populations. Forensic Sci Int Genet 1: 208-211.

16. Butler JM (2011) Advanced Topics in Forensic DNA Typing: Methodology. Academic Press.

17. Barbaro A, Cormaci P (2006) X-STR typing for an identification casework. Int Cong Ser 1288: 513-515.

18. Toni C, Presciuttini S, Spinetti I, Domenici R (2003) Population data of four X-chromosome markers in Tuscany, and their use in a deficiency paternity case. Forensic Sci Int 137: 215-216.

19. Toni C, Presciuttini S, Spinetti I, Rocchi A, Domenici R (2006) Usefulness of X-chromosome markers in resolving relationships: Report of a court case involving presumed half sisters. Int Cong Ser 1288: 301-303.

20. Edelmann J, Lessig R, Klintschar M, Szibor R (2004) Advantages of Xchromosomal microsatellites in deficiency paternity testing: presentation of cases. Int Cong Ser 1261: 257-259.

21. Shin SH, Yu JS, Park SW, Min GS, Chung KW (2005) Genetic analysis of $18 \mathrm{X}$-linked short tandem repeat markers in Korean population. Forensic Sci Int 147: 35-41.

22. Szibor R, Lautsch S, Plate I, Beck N (2000) Population data on the X chromosome short tandem repeat locus HumHPRTB in two regions of Germany. J Forensic Sci 45: 231-233.

23. Whitaker JP, Clayton TM, Urquhart AJ, Millican ES, Downes TJ, et al. (1995) Short tandem repeat typing of bodies from a mass disaster: high success rate and characteristic amplification patterns in highly degraded samples. Biotechniques 18: 670-677.

24. Clayton TM, Whitaker JP, Maguire CN (1995) Identification of bodies from the scene of a mass disaster using DNA amplification of short tandem repeat (STR) loci. Forensic Sci Int 76: 7-15. 
25. Wiegand P, Kleiber M (2001) Less is more--length reduction of STR amplicons using redesigned primers. Int J Legal Med 114: 285-287.

26. Dixon LA, Dobbins AE, Pulker HK, Butler JM, Vallone PM, et al. (2006) Analysis of artificially degraded DNA using STRs and SNPs--results of a collaborative European (EDNAP) exercise. Forensic Sci Int 164: 33-44.

27. Diegoli TM, Coble MD (2011) Development and characterization of two mini-X chromosomal short tandem repeat multiplexes. Forensic Sci Int Genet 5: 415-421.

28. Bai R, Shi M, Yu X, Lv J, Tu Y (2007) Allele frequencies for six miniSTR loci of two ethnic populations in China. Forensic Sci Int 168: e25-28.

29. Chung U, Shin KJ, Park MJ, Kim NY, Yang WI, et al. (2007) Population data of nine miniSTR loci in Koreans. Forensic Sci Int 168: e51-53.

30. Opel KL, Chung DT, Drábek J, Tatarek NE, Jantz LM, et al. (2006) The application of miniplex primer sets in the analysis of degraded DNA from human skeletal remains. J Forensic Sci 51: 351-356.

31. Pizzamiglio M, Marino A, Coli A, Floris T, Garofano L (2006) The use of mini-STRs on degraded DNA samples. Int. Congr. Ser 1288: 498-500.

32. Saiki RK, Scharf S, Faloona F, Mullis KB, Horn GT, et al. (1985) Enzymatic amplification of beta-globin genomic sequences and restriction site analysis for diagnosis of sickle cell anemia. Science 230: 1350-1354.

33. Jeffreys AJ, Wilson V, Thein SL (1985) Hypervariable 'minisatellite' regions in human DNA. Nature 314: 67-73.

34. Jeffreys AJ, Wilson V, Thein SL (1985) Individual-specific 'fingerprints' of human DNA. Nature 316: 76-79.

35. Caskey CT, Hammond HA (1992) Forensic use of short tandem repeats via PCR. Adv Forensic Haemogenetics 4: 18-25.

36. Edwards A, Civitello A, Hammond HA, Caskey CT (1991) DNA typing and genetic mapping with trimeric and tetrameric tandem repeats. Am J Hum Genet 49: 746-756.

37. Sullivan KM, Mannucci A, Kimpton CP, Gill P (1993) A rapid and quantitative DNA sex test: fluorescence-based PCR analysis of X-Y homologous gene amelogenin. Biotechniques 15: 636-638, 640-1.

38. McEwen JE (1995) Forensic DNA data banking by state crime laboratories. Am J Hum Genet 56: 1487-1492.

39. Hellmann A, Rohleder U, Schmitter H, Wittig M (2001) STR typing of human telogen hairs--a new approach. Int J Legal Med 114: 269-273.

40. Marchi E (2004) Methods developed to identify victims of the World Trade Center disaster. Am Lab 36: 30-36.

41. Chung DT, Drábek J, Opel KL, Butler JM, McCord BR (2004) A study on the effects of degradation and template concentration on the amplification efficiency of the STR Miniplex primer sets. J Forensic Sci 49: 733-740.

42. Müller K, Klein R, Miltner E, Wiegand P (2007) Improved STR typing of telogen hair root and hair shaft DNA. Electrophoresis 28: 2835-2842.

43. Drábek J, Chung DT, Butler JM, McCord BR (2004) Concordance study between Miniplex assays and a commercial STR typing kit. J Forensic Sci 49: 859-860.

44. Ross MT, Grafham DV, Coffey AJ, Scherer S, McLay K, et al. (2005) The DNA sequence of the human X chromosome. Nature 434: 325-337.

45. Esteve Codina A, Niederstätter H, Parson W (2009) "GenderPlex" a PCR multiplex for reliable gender determination of degraded human DNA samples and complex gender constellations. International Journal of Legal Medicine 123: 459-464.

46. Israr M, Shahid AA, Rahman Z, Shahzad MS, Ullah O, et al. (2012) Punjabi population data for seven X-chromosome short tandem repeat (X-STR) loci using a new miniplex system. Afr J Biotechnol 11: 10513-10516.

47. Jedrzejczyk M, Jacewicz R, Kozdraj A, Szram S, Berent J (2010) Application of X-STR Loci in Forensic Genetics. Problems of Forensic Sci 82: 141-150.

48. Machado FB, Medina-Acosta E (2009) Genetic map of human X-linked microsatellites used in forensic practice. Forensic Sci Int Genet 3: 202-204.
49. Szibor R (2007) X-chromosomal markers: past, present and future. Forensic Sci Int Genet 1: 93-99.

50. Szibor R, Hering S, Edelmann J (2006) A new Web site compiling forensic chromosome X research is now online. Int J Legal Med 120: 252-254.

51. Szibor R, Hering S, Kuhlisch E, Plate I, Demberger S, et al. (2005) Haplotyping of STR cluster DXS6801-DXS6809-DXS6789 on Xq21 provides a powerful tool for kinship testing. Int J Legal Med 119: 363-369.

52. La Spada AR, Wilson EM, Lubahn DB, Harding AE, Fischbeck KH (1991) Androgen receptor gene mutations in X-linked spinal and bulbar muscular atrophy. Nature 352: 77-79.

53. Butler JM (2009) Fundamentals of Forensic DNA Typing. Academic Press, New York.

54. Aquino J, Peixe C, Silva D, Tavares C, De Carvalho EF (2009) A Xchromosome STR hexaplex as a powerful tool in deficiency paternity cases. Forensic Sci Int Genet (Supp) 2: 45-46.

55. Silveira D, Silva FF, Jesus PR, Whittle MR (2007) Use of X-linked short tandem repeat loci in routine parentage casework. Transfusion 47: 1050-1053.

56. Builes JJ, Manrique A, Aguirre D, Puerto Y, Bravo ML, et al. (2009) Utility of Y- and X-STRs in the research of complex biological relationship. Forensic Science International: Genetics Supplement Series 2: 236-237.

57. Gomes C, Magalhães M, Amorim A, Alves C, Pinto N, et al. (2011) How useful is your $\mathrm{X}$ in discerning pedigrees? Forensic Science International: Genetics Supplement Series 3: e161-e162.

58. Szibor R, Krawczak M, Hering S, Edelmann J, Kuhlisch E, et al. (2003) Use of X-linked markers for forensic purposes. Int J Legal Med 117: 67-74.

59. Edwards MC1, Gibbs RA (1994) Multiplex PCR: advantages, development, and applications. PCR Methods Appl 3: S65-75.

60. Son JY, Lee YS, Choung CM, Lee SD (2002) Polymorphism of nine X chromosomal STR loci in Koreans. Int J Legal Med 116: 317-321.

61. Wiegand P, Berger B, Edelmann J, Parson W (2003) Population genetic comparisons of three X-chromosomal STRs. Int J Legal Med 117: 62-65.

62. Lee HY, Park MJ, Jeong CK, Lee SY, Yoo JE, et al. (2004) Genetic characteristics and population study of 4 X-chromosomal STRs in Koreans: evidence for a null allele at DXS9898. Int J Legal Med 118: 355-360.

63. Poetsch M, Petersmann H, Repenning A, Lignitz E (2005) Development of two pentaplex systems with X-chromosomal STR loci and their allele frequencies in a northeast German population. Forensic Sci Int 155: 71-76.

64. Zarrabeitia MT, Amigo T, Sañudo C, Zarrabeitia A, González-Lamuño D, et al. (2002) A new pentaplex system to study short tandem repeat markers of forensic interest on X chromosome. Forensic Sci Int 129: 85-89.

65. Robino C, Giolitti A, Gino S, Torre C (2006) Development of two multiplex PCR systems for the analysis of $12 \mathrm{X}$-chromosomal STR loci in a northwestern Italian population sample. Int J Legal Med 120:315-318.

66. Bini C, Ceccardi S, Ferri G, Pelotti S, Alù M, et al. (2005) Development of a heptaplex PCR system to analyse X-chromosome STR loci from five Italian population samples. A collaborative study. Forensic Sci Int 153: 231-236.

67. Nakamura Y, Minaguchi K (2010) Sixteen X-chromosomal STRs in two octaplex PCRs in Japanese population and development of 15-locus multiplex PCR system. Int J Legal Med 124: 405-414.

68. Ribeiro Rodrigues EM, Leite FP, Hutz MH, Palha Tde J, Ribeiro dos Santos AK, et al. (2008) A multiplex PCR for $11 \mathrm{X}$ chromosome STR markers and population data from a Brazilian Amazon Region. Forensic Sci Int Genet 2: 154-158.

69. Turrina S, Atzei R, Filippini G, De Leo D (2007) Development and forensic validation of a new multiplex PCR assay with $12 \mathrm{X}$-chromosomal short tandem repeats. Forensic Sci Int Genet 1: 201-204. 
Citation: Israr M, Rafiq S, Ali Shahid A, Hussain H, Rakha A (2014) Scope of X-Chromosomal MiniSTRs: Current Developments. J Forensic Res 5: 1000241. doi:10.4172/2157-7145.1000241

Page 6 of 6

70. Hwa HL, Chang YY, Lee JC, Yin HY, Chen YH, et al. (2009) Thirteen Xchromosomal short tandem repeat loci multiplex data from Taiwanese. Int J Legal Med 123: 263-269.

71. Tariq MA, Ullah O, Riazuddin SA, Riazuddin S (2008) Allele frequency distribution of 13 X-chromosomal STR loci in Pakistani population. Int J Legal Med 122: 525-528.

72. Haas-Rochholz H, Weiler G (1997) Additional primer sets for an amelogenin gene PCR-based DNA-sex test. Int J Legal Med 110: 312-315.

73. Edelmann J, Deichsel D, Hering S, Plate I, Szibor R (2002) Sequence variation and allele nomenclature for the X-linked STRs DXS9895, DXS8378, DXS7132, DXS6800, DXS7133, GATA172D05, DXS7423 and DXS8377. Forensic Science International 129: 99-103.

74. Edelmann J, Szibor R (2003) The X-linked STRs DXS7130 and DXS6803. Forensic Sci Int 136: 73-75.

75. Edelmann J, Szibor R (2005) Validation of the X-linked STR DXS6801. Forensic Sci Int 148: 219-220.

76. Edelmann J, Hering S, Augustin C, Kalis S, Szibor R (2010) Validation of six closely linked STRs located in the chromosome X centromere region. Int J Legal Med 124: 83-87.

77. Hering S, Edelmann J, Augustin C, Dressler J, Szibor R (2008) Forensische Validierung des STR-Markers DXS10160: Strukturanalyse, Allelnomenklatur, Populations, und Kopplungsdaten. Rechtsmedizin 18: 333.

78. Edelman J, Hering S, Michael M, Lessig R, Deischel D, et al. (2001) 16 Xchromosome STR loci frequency data from a German population. Forensic Science International 124: 215-218.

79. Bekada A, Benhamamouch S, Boudjema A, Fodil M, Menegon S, et al. (2010) Analysis of $21 \mathrm{X}$-chromosomal STRs in an Algerian population sample. Int J Legal Med 124: 287-294.

80. Edelmann J, Hering S, Augustin C, Szibor R (2008) Characterisation of the STR markers DXS10146, DXS10134 and DXS10147 located within a $79.1 \mathrm{~kb}$ region at Xq28. Forensic Sci Int Genet 2: 41-46.

81. www.innocenceproject.org

82. Evison MP, Smillie DM, Chamberlain AT (1997) Extraction of singlecopy nuclear DNA from forensic specimens with a variety of postmortem histories. J Forensic Sci 42: 1032-1038.

83. Calafell F, Shuster A, Speed WC, Kidd JR, Kidd KK (1998) Short tandem repeat polymorphism evolution in humans. Eur J Hum Genet 6: 38-49.
84. Schaffner SF (2004) The X chromosome in population genetics. Nat Rev Genet 5: 43-51.

85. Jobling MA, Gill P (2004) Encoded evidence: DNA in forensic analysis. Nat Rev Genet 5: 739-751.

86. Haack K, Hummel S, Hummel B (2000) Ancient DNA fragments longer than 300 bp. Anthropol Anz 58: 51-56.

87. Eliásová I, Mazura I, Smejtek L (2010) DNA analysis of ancient skeletal remains. Folia Biol (Praha) 56: 47-50.

88. Faerman M, Filon D, Kahila G, Greenblatt CL, Smith P, et al. (1995) Sex identification of archaeological human remains based on amplification of the $\mathrm{X}$ and $\mathrm{Y}$ amelogenin alleles. Gene 167: 327-332.

89. Cipollaro M, Di Bernardo G, Galano G, Galderisi U, Guarino F, et al. (1998) Ancient DNA in human bone remains from Pompeii archaeological site. Biochem Biophys Res Commun 247: 901-904.

90. Butler JM, Vallone PM, Coble MD (2007) STRs vs. SNPs: thoughts on the future of forensic DNA testing. Forensic Sci Med Pathol 3: 200-205.

91. Butler JM (2006) Genetics and genomics of core short tandem repeat loci used in human identity testing. J Forensic Sci 51: 253-265.

92. Leclair B, Frégeau CJ, Bowen KL, Fourney RM (2004) Enhanced kinship analysis and STR-based DNA typing for human identification in mass fatality incidents: the Swissair flight 111 disaster. J Forensic Sci 49: 939-953.

93. Hering S, Brundirs N, Kuhlisch E, Edelmann J, Plate I, et al. (2004) DXS10011: studies on structure, allele distribution in three populations and genetic linkage to further q-telomeric chromosome $\mathrm{X}$ markers. Int $\mathrm{J}$ Legal Med 118: 313-319.

94. Boutrand L, Egyed B, Füredi S, Mommers N, Mertens G, et al. (2001) Variations in primer sequences are the origin of allele drop-out at loci D13S317 and CD4. Int J Legal Med 114: 295-297.

95. Rolf B, Bulander N, Wiegand $\mathrm{P}$ (2011) Insertion-/deletion polymorphisms close to the repeat region of STR loci can cause discordant genotypes with different STR kits. Forensic Sci Int Genet 5: 339-341.

96. Hartzell B, Graham K, McCord B (2003) Response of short tandem repeat systems to temperature and sizing methods. Forensic Sci Int 133: 228-234. 